\title{
Shallow marine ostracode turnover in response to environmental change during the Paleocene-Eocene thermal maximum in northwest Tunisia
}

\author{
Abdel-Mohsen M. Morsi ${ }^{\mathrm{a}, *}$, Robert P. Speijer ${ }^{\mathrm{b}}$, Peter Stassen ${ }^{\mathrm{b}}$, Etienne Steurbaut ${ }^{\mathrm{b}, \mathrm{c}}$ \\ ${ }^{a}$ Geology Department, Faculty of Science, Ain Shams University, 11566 Cairo, Egypt \\ ${ }^{\mathrm{b}}$ Department of Earth and Environmental Sciences, K.U. Leuven, B-3001 Leuven, Belgium \\ ${ }^{\mathrm{c}}$ Department of Paleontology, Royal Belgian Institute of Natural Sciences, B-1000 Brussels, Belgium
}

\section{A R T I C L E I N F O}

\section{Article history:}

Received 11 March 2010

Received in revised form 28 October 2010

Accepted 1 November 2010

Available online 12 November 2010

\section{Keywords:}

Paleocene/Eocene boundary

PETM

Ostracoda

Taxonomy

Biostratigraphy

Paleoecology

Paleobiogeography

Tunisia

\begin{abstract}
A B S T R A C T
Two outcrop sections spanning the Paleocene-early Eocene boundary in the Sidi Nasseur-Wadi Mezaz area in northwest Tunisia provided rich ostracode assemblages, yielding 26 species of which three are newly described: Reymenticosta bassiounii, Reymenticosta nasseurensis and Buntonia? tunisiensis. The recorded ostracode fauna and associated foraminifera reflect deposition in a coastal to inner neritic environment. Many of the recorded taxa have a wide geographic distribution throughout the Middle East and North Africa. A correspondence is also observed with West African faunas, especially in the early Eocene fauna. These taxa seem to have originated in West Africa during the Paleocene and migrated northwards during the late Paleocene to early Eocene. Sea-level change and decrease in oxygenation associated with the Paleocene-Eocene thermal maximum (PETM) caused the local disappearance of the South Tethyan Paleocene fauna represented by Paracosta kefensis (morphotype-A), Paracosta aff. paleomokattamensis, Paracypris sp. B Esker, Loxoconcha saharaensis, Buntonia sp. 3 Donze et al., Protobuntonia nakkadii, and probably Reymenticosta bassiounii and R. nasseurensis. Simultaneously, a new but poorly diverse AfroTethyan fauna, mainly represented by Alocopocythere attitogonensis and Buntonia? tunisiensis, settled in the studied part of the basin. After the PETM, diversity increased again as various taxa (e.g. Bairdia aegyptiaca, Reticulina lamellata and Aegyptiana duwiensis) (re)appeared. Although detailed records across the P/ E boundary are still sparse, it appears that the PETM exerted significant influence on the paleobiogeography and composition of Tethyan ostracode faunas.
\end{abstract}

(c) 2010 Elsevier Ltd. All rights reserved.

\section{Introduction}

The Paleocene-Eocene thermal maximum at $55 \mathrm{Ma}$ was a transient period of global climatic warming leading to biotic turnover in marine microbenthos (e.g. Tjalsma and Lohmann, 1983; Speijer et al., 1997; Thomas, 1998, 2007), marine micro- and nannoplankton (e.g. Kelly et al., 1996; Aubry, 1998; Molina et al., 1998; Monechi et al., 2000; Crouch et al., 2003; Tantawy, 2006), carbonate platform systems (Scheibner et al., 2005; Scheibner and Speijer, 2008) and terrestrial mammals (e.g. Gingerich, 2000, 2006). The global patterns of biotic change of these fossil groups are fairly well documented, indicating rapid extinction (benthic foraminifera) evolution (calcareous nannoplankton, planktic foraminifera) and migration (mammals, organic dinoflagellates, hermatypic corals). In contrast, the response of ostracoda to the climatic and paleoceanographic changes associated with the PETM is quite fragmentary and consists of rather disparate individual records. Some authors observe little change in ostracode commu-

\footnotetext{
* Corresponding author. Fax: +20 226842123.

E-mail address: ammorsi@hotmail.com (A.-M.M. Morsi).
}

nities (e.g. Honigstein and Rosenfeld, 1995; Guernet and Molina, 1997; Elewa, 2002), whereas others noted short-term response in a deep-sea locality (Steineck and Thomas, 1996) or intensification of a long-term turnover in Tethyan assemblages (Speijer and Morsi, 2002; Morsi and Speijer, 2003; Morsi and Scheibner, 2009).

The aim of this paper is to document the distribution of ostracodes in the Paleocene/Eocene $(\mathrm{P} / \mathrm{E})$ transition interval by studying two sections (Sidi Nasseur - NAS, Wadi Mezaz - MEZ) in northwest Tunisia (Figs. 1 and 2). These sections yield rich microfaunas, including ostracodes, and provide a unique marginal marine window into early Paleogene climatic and biotic change (Stassen et al., 2009). We address the biostratigraphy, paleoenvironment and paleobiogeography across the $\mathrm{P} / \mathrm{E}$ transition based on ostracodes.

The Paleocene-Eocene succession in the study area is represented by the topmost part of the Maastrichtian to Ypresian El Haria Formation, consisting of marls and shales (Burollet, 1956). It overlies Campanian-Maastrichtian limestones of the Abiod Formation and is overlain by Ypresian phosphatic marls (Chouabine Formation) and nummulitic limestones (El Garia Formation) of the Metlaoui Group (Zaier et al., 1998). Throughout the late Cretaceous and early Paleogene, the sediments of the El 